\title{
From Fast to FeAst: A RITUAL-LitUrgicAl eXPLORATION OF reconciliation in South African cultural contexts
}

Reviewer:

Hennie J.C. Pieterse ${ }^{1}$

Affiliation:

${ }^{1}$ Department of Practical

Theology, University of

Pretoria, South Africa

\section{Correspondence to:}

Hennie Pieterse

e-mail:

pietehjc@absamail.co.za

Postal address:

262 Marraisstraat,

Brooklyn, 0181, Pretoria,

South Africa

Keywords:

ritual; liturgy;

reconciliation; South

African context; Truth and

Reconciliation Commission

Dates:

Received: 15 Aug. 2009

Accepted: 31 Aug. 2009

Published: 25 Nov. 2009

How to cite this article: Pieterse, H.J.C., 2009, 'From

Fast to Feast: A ritualliturgical exploration of reconciliation in South African cultural contexts', Verbum et Ecclesia 30(2), Art. \#86, 1 page. DOI: 10.4102/ ve.v30i2.86

\section{This article is available}

http://www.ve.org.za

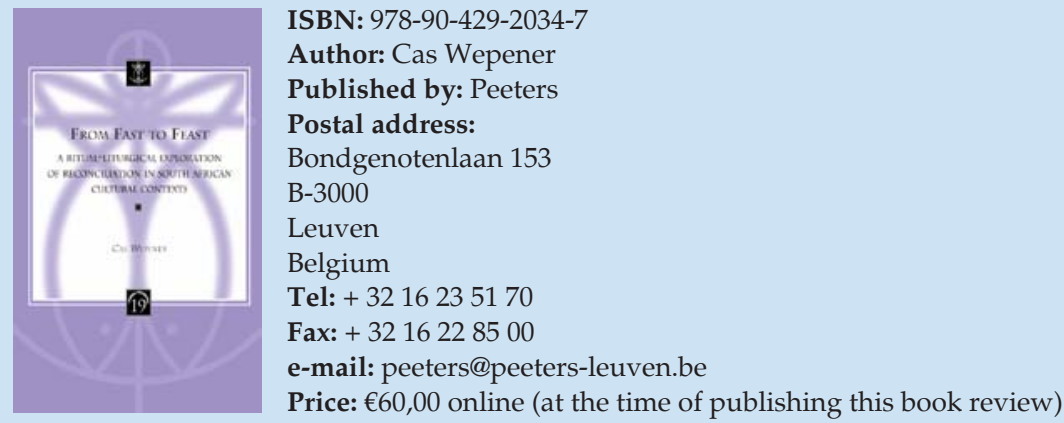

Author: Cas Wepener

Published by: Peeters

Postal address:

Bondgenotenlaan 153

B-3000

Leuven

Belgium

Tel: + 3216235170

Fax: + 3216228500

e-mail: peeters@peeters-leuven.be

Price: $€ 60,00$ online (at the time of publishing this book review)

Cas Wepener is a brilliant and committed young liturgist. This book is based on his doctoral thesis in the Afrikaans language (Stellenbosch University 2004), roughly double the length of this published From Fast to Feast, but this book is a fundamental revision of the thesis. Wepener's work on reconciliation as practised in the liturgy is still very relevant in our post-apartheid context in South Africa and will be topical for some time to come.

By means of a participatory research methodology in liturgical studies he works with three key concepts in his research namely ritual, liturgical inculturation and reconciliation. He has done four ritual probes. Firstly, a brief historical overview of Christian reconciliation rituals during the periods 60-312AD, 312-600AD, 500-1550AD, 1500-1600AD, 1570AD and afterwards. The second probe was a cultural-anthropological study regarding the place of ritual in the process of reconciliation including a contribution from the Gospel of Luke. Furthermore, a descriptive study of the ritual market resulting in typologies of reconciliation rituals, and a South African ethnographic exploration complying with a comparative description of three congregations and their surrounding communities (White, Black and Coloured).

The finding of this research journey is basically that liturgy, in reconciliation and in the unification of the Dutch Reformed Church and the Uniting Reformed Church, is an irreplaceable route. The work of Christ, his reconciliation, is the task of the church. The ritual treasure of the church of Jesus Christ is an instrument that should serve this reconciling work. It is the purpose of this book to improve the church's reconciliation rituals. Cas Wepener's work has also opened windows for the renewal of our liturgy at large. The approach is to formulate liturgical theory and practice in contemporary terms based on tradition and not traditionalism. (c) 2009. The Authors. Licensee: OpenJournals Publishing. This work is licensed under the Creative Commons Attribution License. 